\title{
Disentangling ecological traits related to plant endemism, rarity and conservation status in the Iberian Peninsula
}

\author{
Antoni Buira ${ }^{1} \cdot$ Francisco Cabezas $^{2} \cdot$ Carlos Aedo $^{1}$
}

Received: 7 August 2019 / Revised: 13 February 2020 / Accepted: 25 February 2020 /

Published online: 10 March 2020

(c) Springer Nature B.V. 2020

\begin{abstract}
The Iberian Peninsula and the Balearic Islands are home to 1823 endemic taxa of vascular plants (nearly a quarter of total flora), half of which are narrowly distributed. Here, we explore the ecological traits related to endemism and rarity, and identify the variables other than range size associated with the conservation status. As found in other studies, narrow endemics seem to be prevalently adapted to stressful habitats in which aboveground competition is relatively low. In ecological terms, the greatest richness is found in mid-altitude calcareous rocky habitats, and secondarily in open Mediterranean shrubby formations. Coastal, steppic and alpine habitats contribute to endemism in specific regions and the species that inhabit them tend to have small ranges. A large percentage of narrow endemics (19\%) grow on special substrates, underlying the importance of edaphic islands as drivers of spatial isolation. More productive habitats such as grasslands, wetlands and forests are negatively associated with endemism, and endemics occurring therein tend to be widely distributed. A total of 454 endemic taxa (25\% of total endemics) are regarded as threatened, most of which belong to species-rich lineages. Certain ecological settings appear to be more likely to contain threatened species than others, wet lowlands, coastal habitats and steppic scrub being the most significant in decreasing order. Paradoxically, the areas of occupancy of the species occurring therein are relatively less protected. On the contrary, a large proportion of montane and alpine habitats are protected and many endemics found there are regarded as non-threatened at present. Nevertheless, some centers of endemism located at high elevations are at risk due to global warming.
\end{abstract}

Keywords Range size $\cdot$ Threatened plants $\cdot$ Vulnerable habitats $\cdot$ Red list $\cdot$ Checklist · Edaphic specialization

Communicated by Daniel Sanchez Mata.

Electronic supplementary material The online version of this article (https://doi.org/10.1007/s1053 1-020-01957-z) contains supplementary material, which is available to authorized users.

Antoni Buira

abuira@rjb.csic.es

1 Real Jardín Botánico-CSIC, Plaza de Murillo 2, 28014 Madrid, Spain

2 Depto. Biodiversidad, Ecología y Evolución, Universidad Complutense, 28040 Madrid, Spain 


\section{Introduction}

Following Reveal's definition (Reveal 1981), rarity is merely the current status of an extant organism which, by any combination of biological or physical factors, is restricted either in numbers or area to a level that is demonstrably less than the majority of organisms of comparable taxonomic entities. Thus, in simple terms, rare species are those having low abundance and/or small range (Gaston 1994). Although both traits do not necessarily concur (Rabinowitz 1981), several studies further show that rare species tend to have simultaneously low abundances and small range sizes (e.g. Gaston 1994; Gaston and Blackburn 2000; Yin and He 2014). Rarity is also the main determinant of a species' risk of extinction (Gaston and Fuller 2009). Besides the range and population sizes, the IUCN Red List (last update in 2012) also considers criteria as the rate of decline, the degree of fragmentation, and the potential future threats.

At large scale, endemism and rarity are closely related concepts, since endemic species occur within a defined geographic area and nowhere else (Gaston 1994). The Mediterranean region is distinguished by the great richness of narrow endemic species (i.e. restricted to a well-defined small area; Kruckeberg and Rabinowitz 1985); they account for more than half of the total species endemic to the region (Thompson 2005). Geographic confinement and spatio-ecological isolation have been the primary drivers of speciation in the Mediterranean region (Molina-Venegas et al. 2013; Rundel et al. 2016). Thus, in comparison with widespread species, Mediterranean narrow endemics are more adapted to stressful habitats with low competition (e.g. rocky, sloping and open habitats) and tend to show altitudinal zonation and edaphic specialization (Lavergne et al. 2004; Médail and Verlaque 1997; Thompson et al. 2005).

About a quarter (24\%) of the total native species occurring in the Iberian Peninsula and Balearic Islands are endemic, and nearly half are regarded as narrow endemics (Buira et al. 2017). Iberian endemic plants are accumulated in species-rich lineages (half of the species belong to one of the 25 largest genera) which have radiated mainly during the late Pliocene and Quaternary (Rundel et al. 2016). The species richness is very unevenly distributed; the main centers of endemism are the Balearic Islands, the southwestern and southeastern coasts and the main mountain ranges, i.e. the Pyrenees, the Cantabrian Mountains, the Central System, and particularly the Baetic System. This latter is home to almost half of the total Iberian endemics, including a large portion of narrow endemics. Likewise, Domínguez-Lozano et al. (1996) found that Spanish threatened taxa were concentrated in a relatively small number of regions, highlighting Sierra Nevada, the most endemic-rich area.

Although the distributional patterns of the Iberian endemic and threatened taxa have broadly been examined, so far, any study has focused on exploring the endemism- and rarity-related ecological traits. Many endemic species of recent origin are shown to be inherently rare and at risk of extinction (Davies et al. 2011); however, it is also clear that rarity of several species at present is due to human activity (Di Marco and Santini 2015; Hodgson 1991; Le Roux et al. 2019). In this sense, identifying the ecological and biological characteristics related to both rarity and conservation status may help to discern whether threatened endemics are intrinsically rare or as a result of anthropogenic disturbances. Likewise, some habitats are more likely to harbor threatened species than others, for example, narrow endemics growing on rocky walls of mountainous areas are naturally sheltered and thus appear to be at lower risk of extinction (e.g. Silcok and Fensham 2018). To this effect, finding combinations of sites and ecological variables that are correlated with the occurrence 
of threatened plants may be useful to target conservation strategies for assemblages of vulnerable species.

The huge amount of high quality data from the almost completed Flora iberica project, together with recent thorough monographs and short publications describing new taxa, have enabled us to elaborate an updated list of the Iberian endemic flora. Likewise, the conservation statuses have been revised by adapting the last upgrade of the Spanish Red List (Moreno 2010) and the recently elaborated Portuguese Red List (Carapeto et al. in press) to the taxonomic criteria used here and to the whole study area (i.e. considering the species' global populations). Accordingly, we aim (1) to present an updated list of the Iberian and Balearic endemic taxa including IUCN categories, (2) explore the ecological and biological traits associated with endemism and rarity by comparing the endemic and native flora patterns and using multivariate statistical techniques, and (3) identify the variables other than range size related to the conservation status through techniques of logistic regression.

\section{Materials and methods}

\section{Study area}

The study area corresponds to the Iberian Peninsula, including the whole Pyrenees mountain range (northern side located in France), and the Balearic Islands (Fig. 1). The phytogeographical regions adapted from Buira et al. (2017) have been used to indicate species distributions as well as for some spatial analysis. These regions resulted from a clustering analysis based on the presence/absence data of the endemic species on $50 \times 50 \mathrm{~km}$ cells. The original proposal has been maintained, and only the species-poor grid cells of the largely agricultural central plateau have been separated as a disjointed distinct region $(C P)$. The 12 regions are well defined by the natural geographic features (Fig. 1), including the major mountain ranges of the Iberian Peninsula, i.e. the Pyrenees $(P Y R)$, the Cantabrian Mountains $(C M)$, the Iberian System $(I S)$, the Central System (included within $N W M$ ) and the Baetic System $(B S)$, with the highest point of the study area located in the Sierra Nevada at $3478 \mathrm{~m}$; the two major plateaus $(C P)$; two large valleys, i.e. the Ebro valley (included in $C R E$ ) and Guadalquivir valley (included in $S W Q$ ); and extensive coastal areas $(N W C$ and $S W C$ ). The regionalization reflects a primary longitudinal division of Iberia between the predominantly basic (limestones, marlstones, dolomites and gypsum) eastern regions and the acidic (igneous granites and metamorphic rocks) western regions. It also reflects in part a climatic division between mainly Eurosiberian regions (the three northernmost ones) and Mediterranean regions.

\section{Taxonomic and distribution database}

We prepared an updated checklist (attached as Supplementary Material) of the species and subspecies endemic to the area of study, which was used as a basis of this work. The taxonomic criterion was based mainly on Flora iberica (Castroviejo 1986-2019), though the list was updated with the new taxa published after that work and revised on the basis of more recent thorough monographs (the taxonomic source of each group is noted in the checklist). The list was also contrasted with the latest published floras from the neighboring 


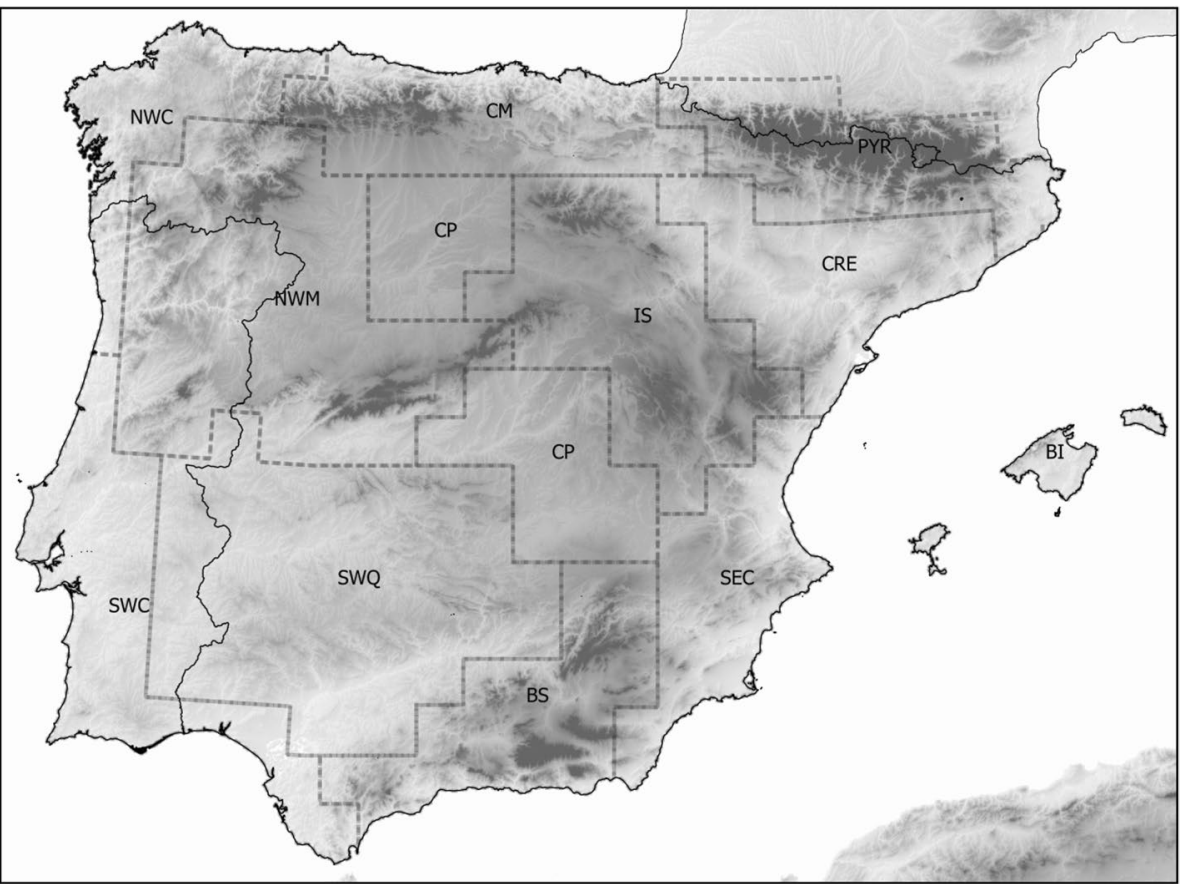

Fig. 1 Phytogeographical regions adapted from Buira et al. (2017). BI Balearic Islands, BS Baetic System, $C M$ Cantabrian Mountains, CP Central Plateau, CRE Catalan Coastal Range and Ebro depression, IS Iberian System, NWC Northwestern Coast, NWM Northwestern Mountains, PYR Pyrenees, SEC Southeastern Coast, $S W C$ Southwestern Coast, $S W Q$ Southwestern Quadrant

countries (i.e. Fennane et al. 1999-2015 for Morocco; Tison and Foucault 2014 for France) to verify the species endemic status.

The endemic taxa distribution data were obtained from Anthos (www.anthos.es) and Flora-On (www.flora-on.pt) projects, which compiled about 70,000 unique records on UTM $10 \times 10 \mathrm{~km}$ cells. Data from the northern size of the Pyrenees were completed with the Atlas Flora Pyrenaea (www.atlasflorapyrenaea.org). The range size of the species was measured by the Area of Occupancy (AOO), i.e. the area within the extent of occurrence which is occupied by a taxon (Gaston 1991), estimated by the total number of $10 \times 10 \mathrm{~km}$ cells in which the species occur. All taxa were classified into four range size levels (very narrow, narrow, wide and very wide) by dividing the total sample into four equal-sized groups.

We additionally calculated for each taxon the Indicator Value (IndVal) (Dufrêne and Legendre 1997), which quantifies the fidelity and specificity of species in relation to the 12 phytogeographical regions. Low IndVal of a taxon in a given region indicates that its presence is sporadic and it is predominantly found in other regions. Taxa with IndVal $<0.15$ in a specific region were classified as occasional, and the rest were classified into three ordered levels of fidelity by dividing the total values of the region into three equal-sized groups. Any taxon exclusive of a region was classified at the 
very least in the lowest category of fidelity. Analyses were done using R 3.5.0 (R Core Team 2018) with the indicspecies (v1.7.6; De Cáceres and Legendre 2009) package.

\section{IUCN categories}

The IUCN categories were obtained from the last updated Red List of Spain (Moreno 2010) and the Red List of mainland Portugal (Carapeto et al. in press); however, they were adapted according to the taxonomic circumscription used in this study. For example, Narcissus nevadensis is considered to have a very narrow range in the Spanish Red List, whereas in Flora iberica is deemed to be widely distributed because different species concepts are used. A total of 40 taxa occurring in both countries (Spain and Portugal) and catalogued in either or both Red Lists were assigned to the lowest category of threat. Likewise, 22 endemic taxa described after the publication of the Spanish Red List were firstly assessed here using information from the original source of publication or personal communications of authors and experts. Taxa whose distribution data were deficient or inconsistent were classified as Data Deficient (DD) and excluded from all the analysis.

Additionally, the number of threatened taxa occurring in $50 \times 50 \mathrm{~km}$ cells was counted and mapped by pie charts together with the weighted endemism (WE) measured on the same scale. That variable was calculated by the sum of the inverse range sizes $(=1 /$ number of grid cells) of the total endemic species occurring in a grid cell.

\section{Ecological and biological traits}

All taxa were classified into the following categories (words in italics are the names of the categories used in results, tables and graphs).

- Habitats: 11 categories adapted from the hierarchical levels 1 and 2 of the EUNIS habitat classification (Davies et al. 2004). These include perennial and annual grasslands (Grassland); Mediterranean dwarf scrub formations (Med. scrub); gypsicolous and halo-nitrophilous steppic scrub (Steppic); heaths and other mesic silicicolous scrub (Heath); alpine vegetation (Alpine); rocky environments (Rocky); deciduous, conifer and mixed forests (Forest); live oaks and secondary sclerophyllous formations (Sclerophyll), bogs, fens, springs, waterbodies shores and temporary ponds (Wetland); coastal marshes, sands and sea-cliffs (Coast); disturbed places and crops (Ruderal).

- Edaphic preference: Indifferent, calcareous $(\mathrm{Ca})$, siliceous $(\mathrm{Si})$ and Special, including gypsum (Gyp), serpentines (Serp), dolomites ( $\mathrm{Dol}$ ) and haline soils ( $\mathrm{Hal})$. Data were mainly obtained from the ecological information of Flora iberica. Checklists of Iberian gypsophytes (Mota et al. 2009) and Baetic Dolomite (Mota et al. 2008) flora were used to complete this information.

- Altitudinal ranges: 0-400 $(<400 \mathrm{~m}), 401-800(<800 \mathrm{~m}), 801-1200(<1200 \mathrm{~m}), 1201-$ $1800(<1800 \mathrm{~m})$ and $1801-3400(<3400 \mathrm{~m})$ meters. They were established by calculating the elevation mean of each taxa and dividing the total sample into five subequalsized groups.

- Life-form categories: phanerophyte $(P h)$, chamaephyte $(\mathrm{Ch})$, hemicryptophyte $(\mathrm{He})$, therophyte (Th) and geophyte (Ge). They were adapted from Raunkiaer system (1934).

- Large lineages: 4 at genus level, i.e. Limonium Armeria, Teucrium and Saxifraga; and 11 at subtribe or tribe level, i.e. Centaureinae, Antirrhineae, Poeae, Sileneae, Alsineae, Loteae, Mentheae, Genisteae, Rubieae, Stachydeae and Geranieae. Only the 15 most 
species-rich lineages were considered, which account for $45 \%$ of total endemic taxa, the rest of species were classified as Other. All these tribes and genera constitute true lineages supported by molecular data.

\section{Endemism-related traits and analysis of rarity}

Chi-square tests were used to determine whether endemic taxa and total native taxa were distributed in the same frequency with regard to categories of habitat, edaphic preference and life-form. The ratio between the frequency of endemic taxa and the frequency of total native taxa for a given category was used to estimate its degree of association with endemism (values $>1$ indicate positive association and values $<1$ indicate negative association). Taking the frequency of total native taxa as expected frequency, significance of association for a given category was assessed by building Bonferroni confidence intervals (Byers et al. 1984). Additionally, a graphical matrix was plotted using the percentages of endemic taxa and total native taxa for habitat categories (rows) within each region (columns).

A correspondence analysis (CA) was carried out to explore relationships among range size categories and categorical plant traits and visualize the data set in a two-dimension plot. Due to the enforced differences on range size in the island territories, the species of Balearic Islands were not included in this analysis. We used the four categories of range size as columns and the ecological traits (i.e. altitudinal range, edaphic preference and habitat), life-forms, large lineages and regions as rows. When a taxon occurred in more than one region, it was assigned to the region with the highest IndVal. The dependency between rows and columns was evaluated using the chi-square statistic. The eigenvalues retained by each dimension (axis) were extracted and the two first dimensions were used to draw a symmetric biplot, in which both rows and columns were represented in the same space using the principal coordinates. FactoMineR package (Lê et al. 2008) was used to compute the CA and factoextra (Kassambara and Mundt 2017) to extract and visualize the results.

\section{Traits associated with IUCN categories and logistic regression}

Nearly all threatened endemic taxa (95\%) fall within the "very narrow" and "narrow" categories $(\mathrm{AOO}<20$ cells of $10 \times 10 \mathrm{~km})$. Thus, to conduct this analysis we selected a subset including all narrow and very narrow taxa (770 taxa) and divided into 3 IUCN similarsized groups: low risk (LC+NT: 332), high risk (VU: 238) and very high risk (EN + CR: 200). A preliminary exploratory analysis was made through chi-square tests. We tested separately whether habitats, altitudinal ranges, regions and lineages were significantly associated with the IUCN categories. Regions were reduced to six by grouping them on the basis of their closest intercluster distance (see Buira et al. 2017). We additionally conducted one-way ANOVA or Kruskal-Wallis and pairwise tests to compare the means of AOO at every level of the IUCN categories. ggplot2 (Wickham 2016) and corrplot (Wei and Simko 2017) R packages were used to plot contingency tables and Pearson residuals.

Logistic regression was carried out to identify which variables had significant effect on the conservation status once the AOO was accounted. Similarly to CA, taxa of Balearic Islands were excluded. A total of four logistic models were built, two of them using a binary response variable (non-threatened: LC or NT; threatened: VU, EN or CR), and the other two using an ordered response variable with three categories (low risk: LC + NT; high risk: $\mathrm{VU}$; very high risk: EN+CR). In turn, two models (one binary and one 3-ordinal) were 
calculated using only the $\mathrm{AOO}$ as independent variable and the other two using the AOO plus several variables, i.e. taxonomic rank (species or subspecies), elevation mean, habitat, life-form, region, and human influence variables. The latter was based on the mean values of the Global Human Influence Index (Wildlife Conservation Society 2005) in which species occur. Lineage category was not used in the regressions, as it has too many levels. A Likelihood Ratio Test was performed on the models to get a sequential analysis of deviance and see the drop in residual deviance when adding each variable one at a time. We finally assessed the predictive ability on each model running a ten-fold cross-validation. MASS R package (Venables and Ripley 2002) was used to fit the ordered logistic models (function polr) and caret package (Kuhn 2008) to validate the models.

\section{Results}

\section{Updated checklist and taxa spatial distribution}

According to this latest update (see "Checklist" table in Supplementary Material), the Iberian-including the whole Pyrenees range-and Balearic flora consists of 1357 endemic species (1823 taxa, including subspecies), which account for $24 \%$ of the total native flora. About $70 \%$ of these taxa occur exclusively in one single phytogeographical region (occasional taxa for a region not considered). A total of 455 taxa (25\% of the total endemics) are classified as threatened (CR: 101, EN: 106 and VU: 248), 1159 as non-threatened (NT: 119 and LC: 1040) and 3 as extinct (EX or EW). A total of 206 taxa (11\%) taxa are classified as DD, mostly represented by Alchemilla (17\%), Limonium (13\%), Taraxacum (8\%) and Armeria (7\%) genera.

The number of threatened taxa per cell (Fig. 2) is highly correlated with the weighted endemism variable (Pearson's correlation $=0.81$ ). The greatest concentrations of threatened taxa are found in the endemic-rich cells of the Baetic Mountains, Majorca and southwestern coast.

\section{Endemism-related ecological traits}

Results of chi-square tests of homogeneity and ratios between the frequencies of endemic taxa and total native taxa for categories of habitat, edaphic preference and life-form are showed in Table A1 (See "Appendix" in Supplementary Material). As regards the representativeness of the habitats, several differences can be observed across regions (Fig. 3). Rocky habitat harbors the greatest number of endemics in many regions ( $B I, B S, C M$ and $P Y R$ ), as well as it is the largest one for the whole territory (Figs. 3, 4a). This habitat is also highly associated with endemism, since the relative portion of total native taxa growing on it is much lower in all situations. Med. scrub habitat is also positively related to endemism and gathers the $15 \%$ of the total endemics (Fig. 4a), being particularly well represented in all eastern regions ( $B I, B S, C P, C R E, I S$ and $S E C)$. Grassland also includes a large portion of endemics in most regions but it is negatively associated with endemism, since the relative frequency of total native species is much higher, just like in Wetland, Ruderal and Forest habitats. Coast habitat consists of many endemic species in the Balearic Islands $(B I)$ and the western Atlantic coast (NWC and particularly $S W C$ ) but it is of little importance in other regions, even if some have coastal land. Steppic is only well represented in some regions, particularly in the semiarid areas of the Ebro depression $(C R E)$, southern 


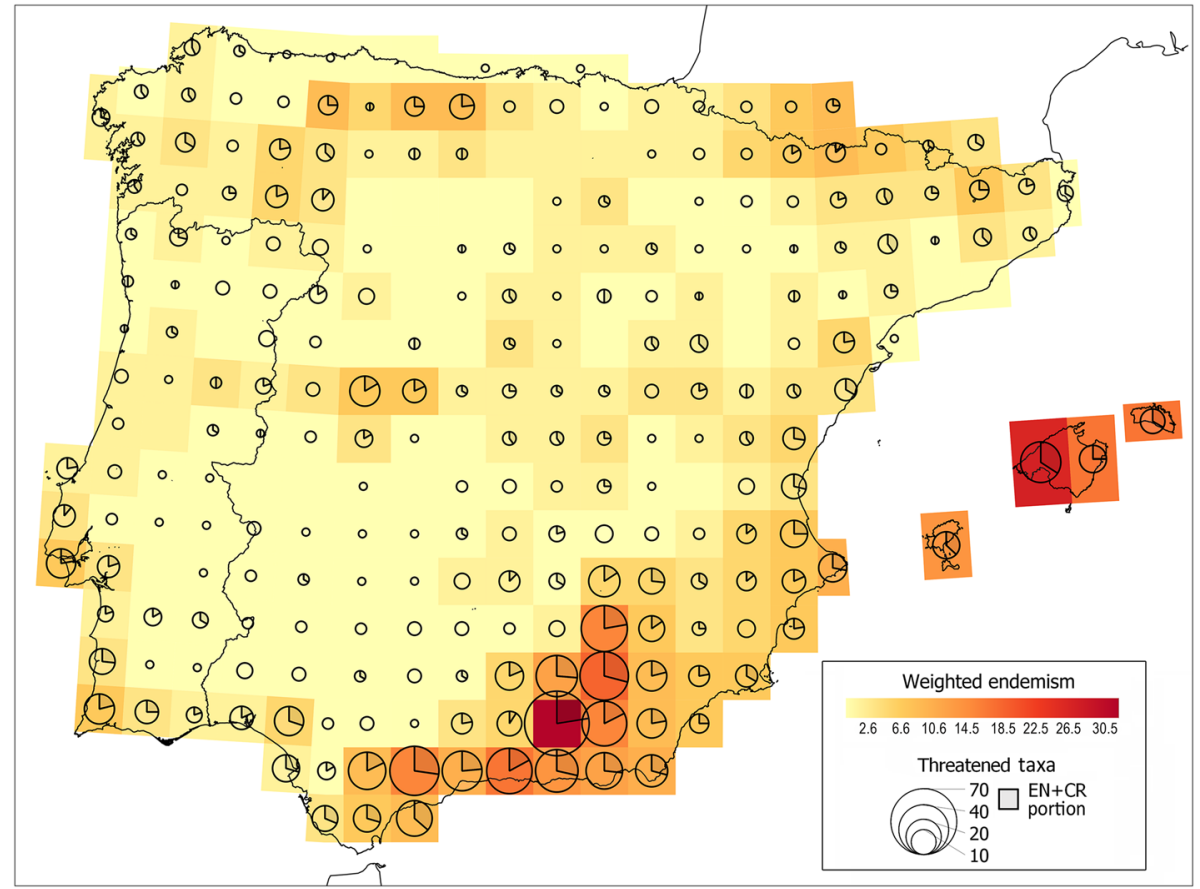

Fig. 2 Threatened taxa occurring in $50 \times 50 \mathrm{~km}$ cells represented by scaled circles (small shaded portion is EN + CR percent) and weighted endemism (WE) represented by yellow-orange-red color scale. WE is calculated by the sum of the inverse range sizes of the total endemic species occurring within each grid cell

plateau $(C P)$ and southeastern Iberia $(S E C)$. Similarly, alpine endemics only occur in the high mountain regions, basically Pyrenees $(P Y R)$, Cantabrian Mountains $(C M)$ and Sierra Nevada (within $B S$ ).

With regard to the edaphic preference, both siliceous $(\mathrm{Si})$ and calcareous $(\mathrm{Ca})$ are positively associated with endemism, although $\mathrm{Ca}$ represents a much larger proportion (41\%) of endemics than $\mathrm{Si}(24 \%)$ (Fig. 4b). The relative portion of native plants for both substrates is instead pretty similar. Indifferent is negatively associated with endemism, while Special shows a strong positive association. Almost $70 \%$ of Iberian taxa growing preferably on gypsum soils are endemic; the proportion is even higher for dolomite and serpentine specialized plants (nearly $85 \%$ ). In contrast, haline soils do include a large number of non-endemic species, and most of the endemic ones are species of the genus Limonium.

No major differences are observed between the altitudinal distribution of the total native taxa and the endemics (Fig. 4c), but a greater percentage of endemic taxa is found in the highlands (above $1500 \mathrm{~m}$ ). As for the life-forms, endemics are mostly represented by chamaephytes $(\mathrm{Ch})$ and hemicriptophytes $(\mathrm{He})$, although the former have a much stronger association with endemism (Fig. 4d). Phanerophytes (Ph), geophytes $(G e)$ and therophytes (Th) forms are less common on the endemics; Th show indeed a strong negative association with endemism. 


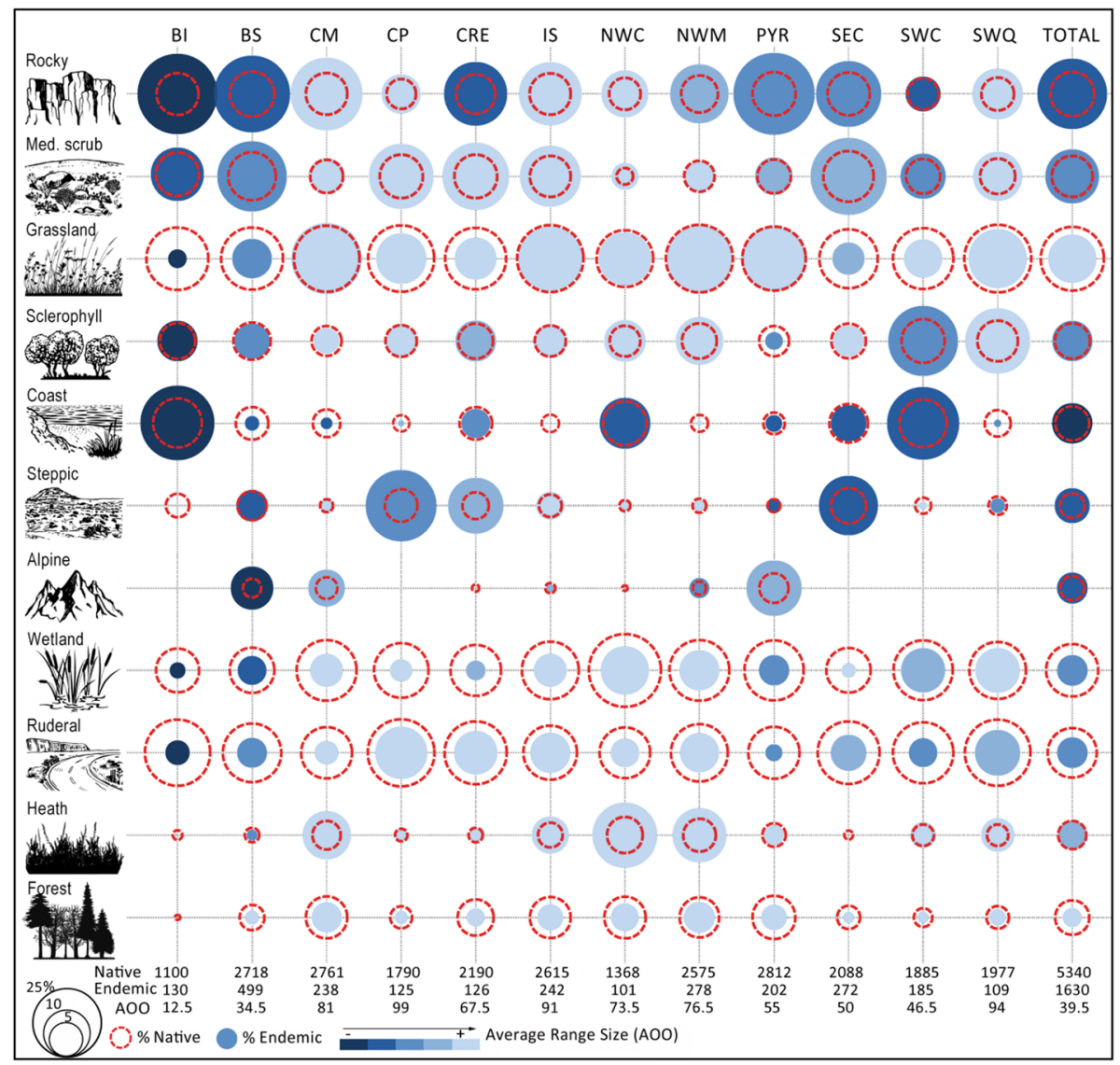

Fig. 3 Balloonplot indicating the percentage of endemic taxa (filled blue circles) and total native taxa (red empty circles) for habitat categories (rows) within each region (columns). Habitats are ordered from top to bottom by the total number of endemics they contain. Blue scale indicates the average range size of the endemics in each situation. The number of native taxa, endemic taxa and range size mean (AOO measured in $10 \times 10 \mathrm{~km}$ cells) per region are indicated at the bottom of the chart

\section{Correspondence analysis of rarity}

The chi-square test (chi-square: $464.98, \mathrm{p}$-value $=6.25 \mathrm{e}-42$ ) shows that range size categories (rows) and plant traits (columns) are significantly associated. The first two axes of the correspondence analysis (Fig. 5) explain $94.2 \%$ of the total variation, particularly the dimension 1 explains the most variance in the solution (85.6\%). The attributes very wide and very narrow are highly discriminating, while narrow and wide are closer to the origin and thereby less differentiated based on the data. The row items $<400 \mathrm{~m}, \mathrm{BS}$, Special, Alpine, Coast, IS, CM, Grassland, $<1200 \mathrm{~m}$, Limonium, Indifferent, Genisteae, and $<3400 \mathrm{~m}$ are the most important traits in decreasing order on the definition of the first dimension. As regard for columns, only very narrow and very wide are well displayed on the first dimension ( $40 \%$ and $50 \%$ of contribution respectively).

The altitudinal ranges $<3400 \mathrm{~m}$ and particularly $<400 \mathrm{~m}$ have an important contribution to the positive pole of the first dimension, indicating that endemics of the 

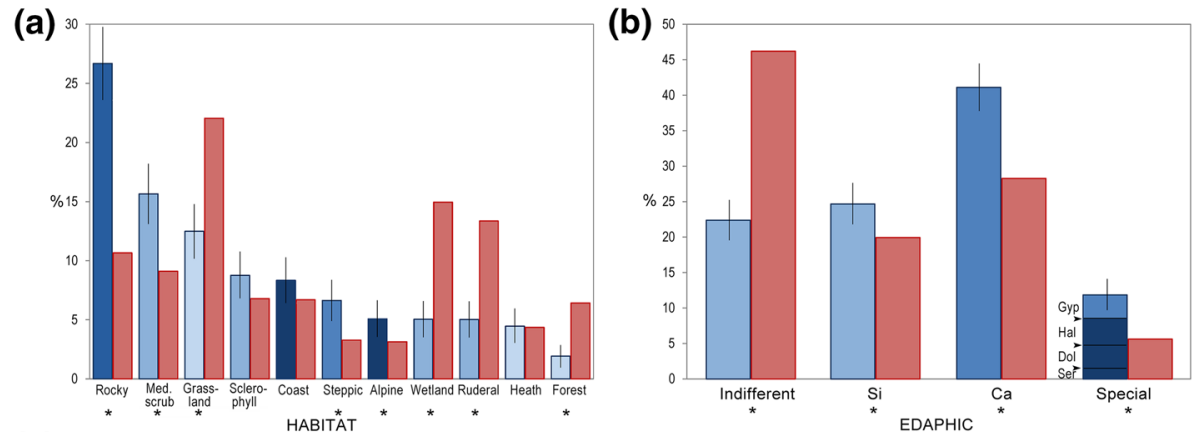

(c)

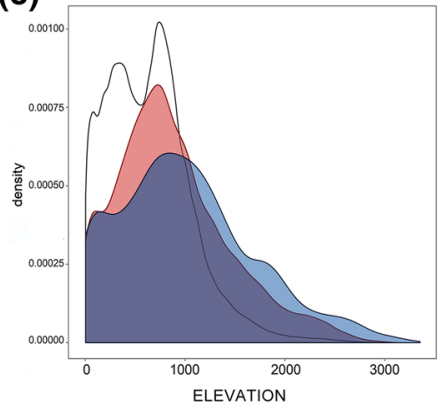

(d)

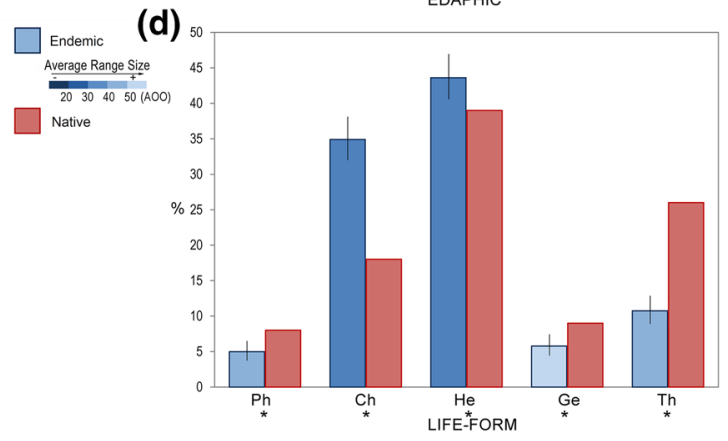

Fig. 4 a Percentage of total endemic taxa (blue) and total native taxa (red) for habitat categories. b Percentage of total endemic taxa (blue) and total native taxa (red) for categories of edaphic preference. c Proportion of total surface area (empty), percentage of total endemic taxa (blue) and percentage of total native taxa (red) along the altitudinal gradient. d Percentage of total endemic taxa (blue) and total native taxa (red) for life-form categories. Figures $\mathbf{a}, \mathbf{b}$ and $\mathbf{d}$ also show for the endemic taxa the average range size (AOO measured in $10 \times 10 \mathrm{~km}$ cells) of each category (blue scaled) and confidence intervals. Categories significantly associated (positively or negatively) with endemism are indicated with an asterisk (*)

most extreme altitudinal belts are more frequently narrowly distributed. By contrast, < $1200 \mathrm{~m}$ contributes to the negative pole and therefore it is more related to wide distributions. All other altitudinal ranges are little differentiated. As regard to the habitats, Alpine and Coast have the strongest relationship with very narrow and narrow attributes, while Heath, Forest and Grassland are highly associated with wide range sizes. However, certain habitats have significant differences in average range size among regions. For instance, alpine endemics from Sierra Nevada $(B S)$ have narrower distributions than those from Pyrenees $(P Y R)$ and Cantabrian Mountains (CM) (Fig. 3). In fact, range sizes of the endemics from Balearics $(B I)$ and Baetic System $(B S)$ are smaller for almost all habitats. Coast endemics have the lowest range size mean, and this is partly due to the large contribution of $B I$ on this habitat to the total.

$\mathrm{Ca}$ and $\mathrm{Si}$ edaphic preferences are both close to the origin (Fig. 5), although both symmetric biplot and average range size (Fig. 4b) show that $\mathrm{Ca}$ is somewhat more related to rarity than $\mathrm{Si}$. Special category contributes the most to the positive pole, so it is highly associated with the rarity attribute, although gypsum (Gyp) subset has larger average range size (Fig. 4b). There is not any strong association between life-forms and categories of range size, only $G e$ and particularly $P h$ are moderately associated 


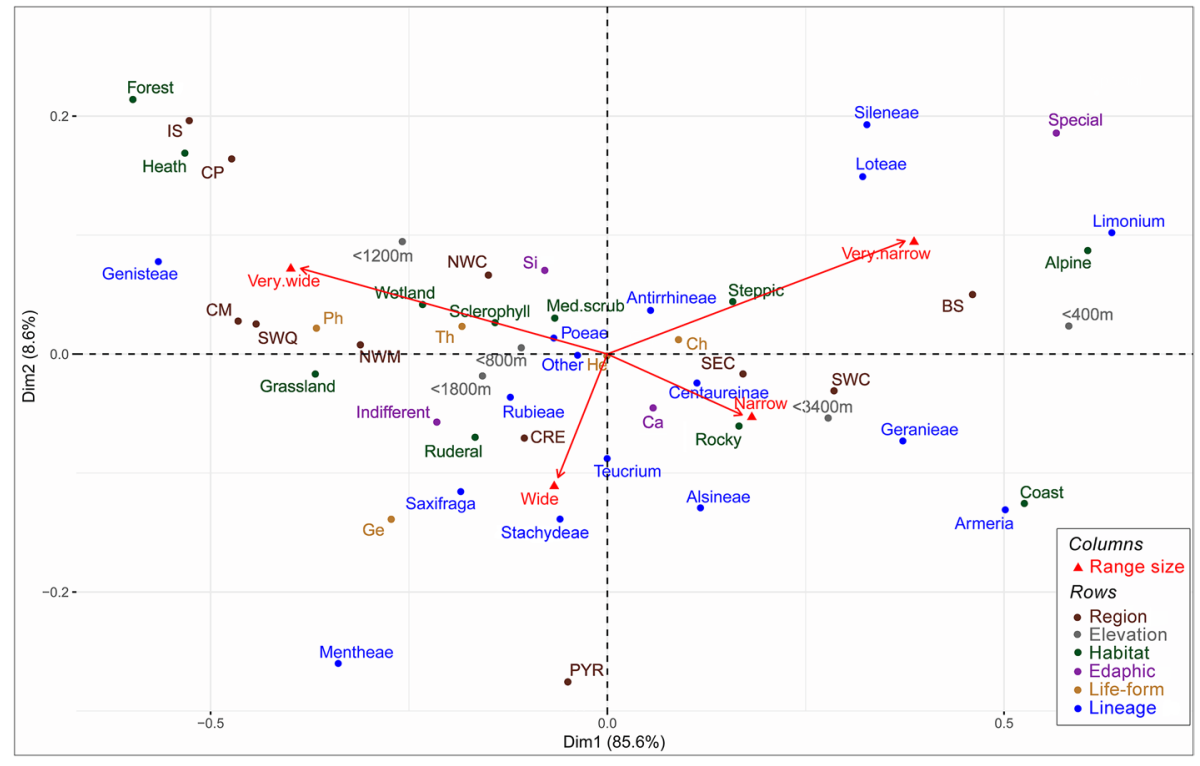

Fig. 5 Symmetric biplot from a correspondence analysis (CA) in which both columns (red triangles) and rows (dots) are represented in the same space using the principal coordinates. Column items are ordinal levels of range size and row items are different plant traits colored by group: phytogeographical region (brown), altitudinal range (grey), habitat type (green), edaphic preference (violet), life-form (orange) and lineage (blue)

with the wide distribution. In terms of the largest endemic plant lineages, Sileneae, Loteae and particularly Limonium are highly associated with the very narrow attribute and Armeria and Geraniae with the narrow one. On the opposite, Mentheae and Genisteae have a strong relationship with the categories wide and very wide respectively.

\section{Traits associated with IUCN categories and logistic regression}

Chi-square tests show that there are significant differences among regions regarding the relative frequency of narrow endemic taxa per IUCN category (Fig. A1 in Online Appendix). BI (Balearic Islands) has a larger portion of non-threatened taxa (LC+NT) than expected by chance. In addition, its averages AOO for VU and EN + CR categories are significantly lower compared with the other regions. $C M+P Y R$ and $C R E+I S$ have also a larger portion of non-threatened taxa $(\mathrm{LC}+\mathrm{NT})$ than expected. Habitats are also significantly associated with the IUCN categories (Fig. A2 in Online Appendix). Wetland, Coast, and Steppic (in decreasing order of magnitude) have larger proportions of threatened taxa than expected, while Sclerophyll and Alpine are the opposite. In addition, Wetland has the highest average AOO for VU category, while Alpine has the lowest one (Fig. A2 in Online Appendix). With regard to the elevation, the lowest altitudinal range $(<400 \mathrm{~m})$ gathers almost a third $(30 \%)$ of the total threatened taxa, while the other four ranges have similar percentages of threatened taxa (between 16 and 19\%). Elevation as continuous variable is very weakly but significantly correlated with the 3 IUCN categories in increasing order (Pearson's correlation $=-0.178$, p-value $=3.4$ e-06). Any significant association between life-forms and IUCN Categories was found. 
Table 1 Comparison of goodness-of-fit measures (residual deviance and AIC) and accuracy (calculated by ten-fold cross-validation) of the four logistic models

\begin{tabular}{llllllll}
\hline & \multicolumn{2}{l}{ Simple model (only AOO) } & & \multicolumn{3}{l}{ Multiple model (all variables) } \\
\cline { 2 - 3 } & Accuracy & Deviance & AIC & & Accuracy & Deviance & AIC \\
\hline $\begin{array}{l}\text { Binary response: threatened/non- } \\
\text { threatened }\end{array}$ & 0.74 & 724 & 728 & & 0.79 & 633 & 688 \\
$\begin{array}{l}\text { 3-Ordinal response: } \\
\text { low risk/high risk/very high risk }\end{array}$ & 0.57 & 1190 & 1196 & & 0.63 & 1080 & 1136 \\
\hline
\end{tabular}

As for plant lineages, the $48 \%$ of the total threatened taxa are gathered in the 15 most species-rich lineages. Lineages and IUCN categories are also significantly associated (Fig. A3 in Online Appendix). Particularly, Limonium, Antirrhineae, Sileneae and Armeria include a larger proportion of threatened taxa than expected by chance, while Teucrium, Mentheae and Stachydeae (all included in the Lamiaceae family) have fewer endangered species than expected. There are no significant differences among plant lineages in the means of AOO.

Measures of goodness-of-fit of logistic regression (Table 1) show that multiple models (using all variables) fit better than simple models (using only AOO). Similarly, the accuracy in predicting independent test observations slightly increase in both multiple models. The sensitivity and specificity measures of the binary models are roughly balanced (results of the binary classification are in "Checklist" table in Supplementary Material). The deviance table of the binary logistic model (Table 2 below) indicates that all the variables except the Human influence have a significant association with the response, but logically AOO is by far the variable that reduces the most the residual deviance of the null model. Although far from AOO, Habitat is the second most relevant variable. Only Coast, Rocky, Steppic and Wetland are significant in the model and all have positive coefficient (Table 2), indicating that plants growing on these habitats are more likely to be threatened. Wetland has the highest effect size followed by Coast. The taxonomic rank has also a positive coefficient, indicating that there is a higher relative frequency of threatened taxa at the species level than at the subspecies level. The two significant levels of region are $C M+P Y R$ and $C R E+I S$ and both have negative coefficient. Coefficients of the 3-ordinal logistic models are not shown but the significant variables are the same.

\section{Discussion}

\section{Endemism- and rarity-related ecological traits}

Historical and geographic factors are the main drivers of isolation and speciation processes, and for this reason the southeastern Iberia $(B S)$ and the Balearic Islands $(B I)$ are the richest areas in narrow endemics. However, species ecology is also decisive for the endemics to flourish in certain regions (Thompson et al. 2005). In terms of ecological characteristics, the greatest richness of endemics in the Iberian Peninsula is found in mid-altitude rupicolous habitats. Open Mediterranean scrub like low maquis are also highly related to 
Table 2 Outputs of binary logistic regression using conservation status (threatened/non-threatened) as dependent variable and logarithm of AOO, elevation mean, taxonomic rank, life-form, habitat, region and human influence as predictors. All continuous predictors are mean-centered and scaled by 1 standard deviation

\begin{tabular}{|c|c|c|c|c|c|}
\hline & Estimate & SE & $\mathrm{z}$ value & $\operatorname{Pr}(>|z|)$ & \\
\hline (Intercept) & -1.16 & 0.51 & -2.30 & 0.02 & $*$ \\
\hline $\mathrm{AOO}$ & -1.52 & 0.14 & -10.77 & 0.00 & $* * *$ \\
\hline Elevation mean & -0.15 & 0.19 & -0.79 & 0.43 & \\
\hline Species rank & 0.82 & 0.22 & 3.97 & 0.00 & $* * *$ \\
\hline Life-form Ge & -0.14 & 0.53 & -0.25 & 0.80 & \\
\hline Life-form $\mathrm{He}$ & 0.34 & 0.23 & 1.47 & 0.14 & \\
\hline Life-form Ph & 1.07 & 0.65 & 1.91 & 0.06 & \\
\hline Life-form Th & 0.83 & 0.39 & 2.13 & 0.04 & $*$ \\
\hline Alpine & -0.71 & 0.58 & -1.24 & 0.21 & \\
\hline Coast & 2.03 & 0.79 & 2.58 & 0.01 & $* *$ \\
\hline Forest & 0.90 & 0.64 & 1.41 & 0.16 & \\
\hline Grassland & 1.09 & 0.53 & 2.07 & 0.06 & \\
\hline Med. scrub & 0.75 & 0.49 & 1.52 & 0.13 & \\
\hline Rocky & 1.25 & 0.44 & 2.86 & 0.00 & $* * *$ \\
\hline Ruderal & 0.96 & 0.71 & 1.35 & 0.18 & \\
\hline Steppic & 1.27 & 0.60 & 2.08 & 0.04 & $*$ \\
\hline Wetland & 2.55 & 0.60 & 4.28 & 0.00 & $* * *$ \\
\hline $\mathrm{CM}+\mathrm{PYR}$ & -0.69 & 0.33 & -2.07 & 0.04 & $*$ \\
\hline $\mathrm{CRE}+\mathrm{IS}+\mathrm{CP}$ & -0.84 & 0.35 & -2.42 & 0.02 & $*$ \\
\hline NWC + NWQ & 0.00 & 0.33 & 0.00 & 1.00 & \\
\hline SWC + SWQ & -0.20 & 0.39 & -0.52 & 0.60 & \\
\hline Human influence & 0.00 & 0.10 & 0.15 & 0.87 & \\
\hline
\end{tabular}

Analysis of deviance table (drop in residual deviance when variables are added sequentially)

\begin{tabular}{llrllll}
\hline & Df & Deviance & Resid. Df & Resid. Dev & $\operatorname{Pr}(>$ Chi) & \\
\hline NULL & & & 680 & 910.4 & & $* * *$ \\
AOO & 1 & 182.54 & 679 & 727.86 & 0.00 & $* * *$ \\
Elevation mean & 1 & 15.62 & 678 & 712.24 & 0.00 & $* * *$ \\
Species rank & 1 & 12.16 & 677 & 700.08 & 0.00 & $*$ \\
Life-form & 4 & 10.52 & 673 & 689.56 & 0.03 & $* * *$ \\
Habitat & 9 & 29.38 & 664 & 660.18 & 0.00 & $* *$ \\
Region & 4 & 14.55 & 660 & 633.61 & 0.00 & 0.99 \\
Human influence & 1 & 0.01 & 659 & 633.6 & \\
\hline
\end{tabular}

Null deviance: 910.4 on $680 \mathrm{df}$. Residual deviance: 633.61 on $660 \mathrm{df}$. AIC model: 687.61

Signif. codes: 0 ‘***’ 0.001 '**’ 0.01 '*’ 0.05 '? 0.1

endemism; while coastal habitats, steppic scrub and alpine formations are relevant in some specific regions. All these habitats usually contain a high number of narrow endemics, and consequently most of them are also positively associated with the range size rarity. This pattern of endemics predominantly inhabiting rocky and open shrubby habitats is 
consistent with that observed in many other Mediterranean regions (e.g. Dimopoulos et al. 2016; Lavergne et al. 2004; Médail and Verlaque 1997; Quézel and Médail 2003).

Narrow endemic species are therefore more adapted to stressful habitats in which aboveground competition is relatively low. Succession to dense vegetation in steep, open and rocky habitats is slow or even prevented by local geomorphology and soil aridity (Escudero 1996). Besides impeding vegetation succession, these harsh habitats remain relatively unchanged in relation to the human activity and grazing animals (Lavergne et al. 2005). This habitat stability may be crucial for the persistence of endemic species (Thompson et al. 2005). Grasslands also contain a substantial portion of Iberian endemics; however, this habitat is negatively related to endemism, just like wetlands, ruderal communities and forests. Endemics characteristic of these habitats have in addition larger range sizes on average. The scarcity of narrow endemics in more productive habitats (e.g. forests, grasslands or wetlands) is largely attributable to its inability to compete for resources (Drury 1974; Lavergne et al. 2004).

Coastal habitats foster endemism, although this is only significant in the southern Atlantic coast and the Balearic Islands. The great diversity of coastal habitats in both regions, including cliffs and extensive sand plains and dunes (Pereira et al. 2016), together with the maritime influence that generates regional climatic stability (Harrison and Noss 2017), have likely played an important role to create centers of endemism. Coastal endemics are furthermore highly associated with the range size rarity (Fig. 5) and, indeed, they have the smallest range size on average. This can be partially explained by the high contribution of the island endemics to this group (36\%), but also by the limited availability of coastal habitats, which have been dramatically altered throughout most of the territory. In fact, the overall lowland endemics (altitudinal range $<400 \mathrm{~m}$ ) have narrower ranges than expected by chance. The intense human impact and the consequent reduction of favorable habitats, along with the greater interspecific competition due to the relative increased number of native and exotic species in low-lying areas (Médail and Verlaque 1997), have most probably contributed to constraint the range of lowland endemics.

Our results also show that alpine endemics or those with high elevation optimum $(>1800 \mathrm{~m})$ are more likely to be rare. However, most of the high elevation specialists with narrow distributions occur in the Baetic System (68\%), particularly in Sierra Nevada. High elevation ecosystems have been shown to remarkably increase the speciation rate and foster the endemism in certain cold-adapted plant lineages (Hughes and Atchison 2015; Ohlemüller et al. 2008). The Cantabrian and Pyrenees alpine habitats are indeed positively associated with endemism (Fig. 3), but endemics occurring there have commonly larger ranges because the high mountains appear on a continuum. Wide ranges have also been observed on the alpine endemics of European Alps (Smyčka et al. 2017). Thus, some species like Saxifraga praetermissa, Festuca glacialis or Oreochloa elegans are found in numerous summits of the Pyrenean-Cantabrian range. In contrast, Sierra Nevada has a modest size and is geographically isolated; thereby it acts as a "sky island" and most of the endemics occurring in the highest belt are confined to a small area.

With regard to the soils, Iberian endemics show either a strong preference or avoidance to calcareous substrates; endemics tolerant to both siliceous and calcareous soils are uncommon. Flora of calcareous substrates is on balance richer in endemic species; this is particularly noticeable in some habitats, for example, over $60 \%$ of rupicolous endemics grow preferably on limestone bedrocks. Many authors have pointed out the positive association between limestone and dolomites substrates and endemism (Major 1988; Médail and Verlaque 1997). These lithologies generally provide harsher environments with low competition and foster thermophilous and xerophilous species (Médail and Verlaque 1997). On 
the other hand, Smyčka et al. (2017) found that calcareous glacial refugia hold a substantially higher proportion of alpine endemics than siliceous ones. Carbonate rocks are generally more prone to create microrefugia by its high topographic relief, enabling species to survive periods of climatic oscillation into more favorable positions (Dobrowski 2011; Harrison and Noss 2017). We can found some examples of paleoendemics growing on calcareous rocky habitats in the Pyrenees, such as Ramonda myconi, Borderea pyrenaica or Borderea chouardii.

Perhaps the best illustration of edaphic specialization in the Iberian Peninsula is that of the gypsophile flora, which is restricted to gypsum outcrops in semiarid areas of the eastern side. In these climatic conditions, the physical and chemical limitations imposed by gypsum soils have the strongest impact on plant development (Escudero et al. 2015), giving rise to a specialized flora very rich in endemic plants (nearly $70 \%$ of endemism). Although the range size rarity of the gypsum Iberian endemics has been stressed (Escudero et al. 2015; Mota et al. 2017), our results show that this ecological trait is not as constraining as others. About $22 \%$ of the total gypsum endemics are certainly very narrowly distributed (e.g. Teucrium lepicephalum); however, there are many (27\%) with very wide ranges, like Herniaria fruticosa that can be found in almost all the Iberian gypsum outcrops. Distinction between dolomitophile and calcicole trait is not always easy and precise (Mota et al. 2008). Recognized dolomite and serpentine specialized plants are basically found in the Baetic range and, unlike gypsum flora, are highly associated with rarity. In any event, the large percentage of edaphic specialists within the Iberian endemic flora (12\% of the total) and particularly in the group of narrow endemics (19\%), highlight the importance of edaphic islands as drivers of spatial isolation and allopatric divergence at regional scale (Harrison and Noss 2017).

The special features of the aforementioned habitats also determine the dominant lifeforms, and as in other regions of the Mediterranean Basin (e.g. Georghiou and Delipetrou 2010; Giménez et al. 2004; Quézel 1995) endemics are mostly represented by chamaephytes and short hemicryptophytes. This is in line with Verdú and Pausas (2013), which found phylogenetic evidence of higher diversification in herbaceous and subshrub clades in the Mediterranean region. On the opposite, we found that annual plants are negatively associated with endemism. Annual plants are capable to avoid harsh conditions by remaining in the seed bank or limiting their life cycle to short favorable periods. This reduces their probabilities of extinction (Baldwin 2014), but also might entail a lower rate of speciation of annual lineages (e.g. Soltis et al. 2013). It could explain the unbalanced proportions found between native and endemic species in relation to annual plants.

\section{Characteristics and patterns of threatened taxa}

Range size was the most determinant variable when predicting the conservation status of Iberian endemics, which is logical given that AOO is one of the assessment criteria used in the IUCN. Although this was foreseeable, it reinforces the previously observed trend (Gaston and He 2010) that occupancy measured on a medium-scale (e.g. using $10 \times 10 \mathrm{~km}$ cells) is broadly proportional to population size. It also indicates that the distribution pattern defined as sparse (Rabinowitz 1981), i.e. widespread species that never occur at high densities, is unusual in endemic species, while it is known to be frequent in Iberian nonendemic threatened species. Notwithstanding the above, there are several cases in which range size is not in line with conservation status. In this way, we have identified some 
geographical and ecological settings that significantly condition the conservation status of the species once the effect of AOO is accounted.

Lack of proportionality between range size and abundance is particularly common in endemics of small islands. For example, Galium friedrichii and Carduus ibicensis, endemic to Pytyuses (small Balearic Islands), are regarded as rare at the spatial scale of this study but they occur at levels of abundance greater than those of many other non-endemic species found there. Something similar happens with endemics of high mountains that function as 'sky islands'. For example, Viola crassiuscula and Lepidium stylatum grow on the high lands of Sierra Nevada and are found in just three $10 \times 10 \mathrm{~km}$ cells each; however they are not regarded as threatened because occur very abundantly throughout the suitable habitat of the mountaintop. All this partially explains the significantly lower average AOO of the threatened plants from the Balearic region as well as from the alpine habitat. Endemics occurring in the Pyrenees, Cantabrian Mountains and Iberian System are also somewhat less likely to be threatened than those of the other regions. Mountainous territories are in general less disturbed in terms of land-use changes and fragmentation, and they normally tend to have a proportionally lower number of species at risk (e.g. Médail and Verlaque 1997; Silcok and Fensham 2018).

Wetland habitats are not positively associated with endemism and rarity (Figs. 4, 5), but instead the endemics growing there are very likely to be threatened. One of the reasons is that most hygrophilous endemics grow on peat bogs, temporary ponds and damp meadows, whose real occupancies within the $10 \times 10 \mathrm{~km}$ cells are generally very small. On the other hand, wetlands have severely been altered in the Mediterranean region by numerous causes, including desiccation, changes on the hydrological regime, pollution, overgrazing or exotic plant invasions (Rhazi et al. 2001; Zacharias and Zamparas 2010). Thus, some species growing in wet lowland areas such as Rhaponticum longifolium and Succisella carvalhoana have relatively large range sizes and number of locations, but they are regarded as vulnerable since face population reduction, severe fragmentation and continuing decline (Carapeto et al. in press). Another extreme example is that of the critically endangered Avellara fistulosa, which was recorded from several swampy areas in the western and southwestern Iberian coast throughout the twentieth century, and at present only one extant population (recently reintroduced in another locality) is confirmed in Doñana National Park (SW Spain) (Fernández-Mazuecos et al. 2016).

Coastal and steppic habitats also appear to have more threatened taxa than expected by chance. As stated, human action has shaped the current range of many coastal endemics and some populations of various taxa such as Linaria polygalifolia subsp. lamarkii or Seseli farrenyi are documented to have disappeared over the last two decades due to the increasing pressure from tourism (Plaza and Rodríguez 2009; Rovira 2008). On the other hand, the habitat fragmentation in steppic areas caused mainly by intensive agriculture has severely reduced the range and population size of some endemics such as Vella pseudocytisus subsp. pseudocytisus (Benito et al. 2004) or Linaria nigricans (Peñas et al. 2011) that have both co-evolved with traditional farming.

Plant lineages are significantly associated with IUCN categories, thus endemic species of Geranieae, Sileneae, Limonium or Armeria are more likely to be narrowly distributed and threatened than expected by chance. On the contrary, lineages like Teucrium, Stachydeae, Mentheae and Saxifraga are more likely to consist of wide range size and/or non-threatened endemics. It should be noted that some lineages that are likely to be rare have frequently apomictic reproduction (e.g. Limonium; Róis et al. 2016) or hybridization (e.g. Armeria Fuertes-Aguilar and Nieto-Feliner 2003;) and they tend to create small but distinct populations that sometimes have been considered as species. 
Nevertheless, the effect of taxonomic inflation has been diminished here by considering some of these species as Data Deficient. In any event, the results suggest that closely related species tend to have more similar biologies, and thus they are also likely to have more similar abundances and range sizes. Likewise, it supports the hypothesis that rarity may be a product of phylogenetic constraint as well as independent adaptation (Gaston 1994).

On the other hand, the Iberian threatened taxa match the previously observed pattern for rare species (Schwartz and Simberloff 2001) to be gathered in species-rich lineages (nearly half threatened taxa belong to one of the 15 largest lineages). Most species-rich plant lineages of the Iberian endemic flora are in addition supposed to be recently diversified (Buira et al. 2017; Rundel et al. 2016). Thus, many Iberian threatened species belonging to rapidly diversifying lineages, in which both extinction and speciation are quick (Davies et al. 2011; Knapp 2011), would be just intrinsically rare and at risk of extinction.

\section{Conservation guidance}

The large number of taxa classified as Data Deficient (11\%) as well as uncatalogued potentially threatened taxa (false positives in the binary classification, see "Checklist" table in Supplementary Material) make it advisable the revision and data acquisition for some taxa included in the list. With regard to conservation practice, according to Gaston and Fuller (2008), it is recommendable to identify not only the sites where very rare species at high risk of extinction occur, but also those harboring species that are suffering population depletions. In this sense, we have recognized and ranked some ecological settings (wetlands $>$ coastal habitats $>$ steppic habitats) in which human impact is greater and are more likely to contain vulnerable species.

Agriculture, biological invasions and urbanization have been identified as the main drivers of plant extinction in Mediterranean hotspots (Le Roux et al. 2019). The former particularly affects steppic habitats while the two latter impact coastal habitats more intensely. Despite that, only $25 \%$ of the AOO of the steppic threatened endemics and about $45 \%$ of the coastal ones occur within terrestrial protected areas (mean for total threatened taxa is about 55\%). Gaps in conservation of steppic Iberian flora (particularly gypsophile) were already detected (Martínez-Hernández et al. 2011), and other authors have proposed including some of the massive gypsum outcrops in a micro-reserve network (Mota et al. 2011; Escudero et al. 2015). Similar actions are even more urgently needed in coastal areas, particularly in the most species-rich spots of the southern half. Protected areas should also ensure the effective protection of plant communities, since the current pressure from tourism is untenable in almost every Iberian coastal area, whether or not they are protected.

On the contrary, $92 \%$ of occupancy of threatened alpine endemics and $67 \%$ of those inhabiting rocky habitats occur within protected areas. Furthermore, many montane and alpine narrow endemics are not currently regarded as threatened. Nevertheless, it must be taken into account that warming effects are predicted to be strong at high elevations and centers of endemism situated there are very vulnerable as a whole (Ohlemüller et al. 2008). Reductions in snow cover, faster melting and decreases in soil moisture may lead to range shifts, alterations in species composition and dominances and high extinction risk (CaraDonna et al. 2014; Munson and Sher 2015). This is particularly alarming in the isolated Sierra Nevada, where the permafrost has drastically declined since the second half of the twentieth century (Gómez-Ortiz et al. 2014) and many of its endemics and threatened plants occur on alpine bogs and marshy grasslands highly conditioned by the 
snow dynamics (Pérez-Luque et al. 2015). These potential future threats have often been neglected in the assessments, and perhaps some uncatalogued alpine endemics should be reconsidered for inclusion. Direct conservation actions are limited beyond seeding or translocation attempts. Efforts should rather be aimed to assessing and monitoring the effects of climate change on plant biodiversity, as for instance project GLORIA (www.gloria.ac.at) do in six target Spanish high mountain regions.

Even though wetlands are not particularly rich in endemics, they are undoubtedly priority habitats for plant conservation. Firstly, because a large proportion of non-endemic Iberian threatened taxa (about 30\%) occur in this type of habitats. Secondly, wetlands endemics are characterized by its taxonomic distinctness, since its genera composition is the most dissimilar of all the habitats compared. Wetland threatened endemics are fairly covered in the territory (60\% occur within protected areas), but still they are highly affected by the increasingly hydrological changes. Le Roux et al. (2019) have shown that hydrological disturbance is precisely the primary driver of plant extinctions in biodiversity coldspots. Likewise, wetlands are also very vulnerable to drought under future climate change scenarios (Silcock and Fensham 2018). Thus, its conservation depends not only on the preservation of sites, but also on the proper water management.

Acknowledgements We thank all the authors of the taxonomic treatments of Flora iberica, used to compile the list of the Iberian and Balearic endemic vascular flora, as well as all the authors of the Spanish and Portuguese Red Lists which thoroughly catalogued the plant species. We also thank to M. Porto and X. Font to provide us data from Flora-on and BDBC respectively.

Author contributions First author designed the study, processed and analyzed the data and wrote the manuscript. Both other authors contributed to the final version of the manuscript.

Funding This work has been funded by the Spanish Government through the Flora iberica project (CGL2017-85204-C3-1-P).

\section{Compliance with ethical standards}

Conflict of interest The authors declare that they have no conflict of interest.

\section{References}

Anthos (2019) Sistema de Información sobre las plantas España. https://www.anthos.org. Accessed 30 May 2019

Atlas Flora Pyrenaea (2019) POCTEFA project. https://www.florapyrenaea.com/florapyrenaea/index.jsp. Accessed 30 May 2019

Baldwin BG (2014) Origins of plant diversity in the California Floristic Province. Annu Rev Ecol Evol Syst 45:347-369. https://doi.org/10.1146/annurev-ecolsys-110512-135847

Benito M, Calleja JA, Del Valle E, Domínguez F, Galicia D, Hernández-Bermejo E, Herrera-Molina F, Moreno JC, Prados J, Sainz H, Sánchez R, Vivero JL (2004) Vella pseudocytisus L. subsp. pseudocytisus. In: Bañares Á, Blanca G, Güemes J, Moreno JC, Ortiz S (eds) Atlas y Libro Rojo de La Flora Vascular Amenazada de España. Dirección General de Conservación de la Naturaleza, Madrid, p 1069

Buira A, Aedo C, Medina L (2017) Spatial patterns of the Iberian and Balearic endemic vascular flora. Biodivers Conserv 26:479-508

Byers C, Steinhorst R, Krausman P (1984) Clarification of a technique for analysis of utilization-availability data. J Wildl Manag 48(3):1050-1053. https://doi.org/10.2307/3801467

CaraDonna PJ, Iler AM, Inouye DW (2014) Shifts in flowering phenology reshape a subalpine plant community. Proc Natl Acad Sci 111:4916-4921. https://doi.org/10.1073/pnas.1323073111 
Carapeto A, Francisco A, Pereira P, Porto M (eds), in press. Lista Vermelha da Flora Vascular de Portugal Continental. Sociedade Portuguesa de Botânica, Associação Portuguesa de Ciência da VegetaçãoPHYTOS e Instituto da Conservação da Natureza e das Florestas, Lisboa

Castroviejo S (1986-2019) Flora iberica, vols. 1-18, 21. Real Jardín Botánico-CSIC, Madrid [detailed list of volume editors and genera authors at www.floraiberica.org]

Davies CE, Moss D, Hill MO (2004) EUNIS habitat classification revised 2004. Rep. to Eur. Environ. Agency-European Top. Cent. Nat. Prot. Biodivers. https://www.eea.europa.eu/themes/biodiversity/ eunis/eunis-habitat-classification. Accessed 30 May 2019

Davies TJ, Smith GF, Bellstedt DU, Boatwright JS, Byterbier B, Cowling RM, Forest F, Harmon LJ, Muthama Muasya A, Schrire BD, Steenkamp Y, Van der Bank M, Savolainen V (2011) Extinction risk and diversification are linked in a plant biodiversity hotspot. PLoS Biol 8:e1000620. https://doi. org/10.1371/journal.pbio.1000620

De Cáceres M, Legendre P (2009) Associations between species and groups of sites: indices and statistical inference. Ecology 90:3566-3574

Di Marco M, Santini L (2015) Human pressures predict species' geographic range size better than biological traits. Glob Chang Biol 21:2169-2178. https://doi.org/10.1111/gcb.12834

Dimopoulos P, Raus T, Bergmeier E, Constantinidis T, Iatrou G, Kokkini S, Strid A, Tzanoudakis D (2016) Vascular plants of Greece: an annotated checklist. Supplement Willdenowia 46:301-347. https://doi. org/10.3372/wi.46.46303

Dobrowski SZ (2011) A climatic basis for microrefugia: the influence of terrain on climate. Glob Chang Biol 17:1022-1035. https://doi.org/10.1111/j.1365-2486.2010.02263.x

Domínguez-Lozano F, Galicia-Herbada D, Moreno-Rivero L, Moreno-Saiz JC, Sainz-Ollero H (1996) Threatened plants in peninsular and balearic Spain: a report based on the EU habitats directive. Biol Conserv 76:123-133. https://doi.org/10.1016/0006-3207(95)00107-7

Drury WH (1974) Rare Species. Biol Conserv 6:162-169. https://doi.org/10.1016/0006-3207(74)90061-5

Dufrêne M, Legendre P (1997) Species assemblages and indicator species: the need for a flexible asymmetrical approach. Ecol Monogr 67:345-366. https://doi.org/10.1890/0012-9615(1997)067[0345:SAAIS $\mathrm{T}] 2.0 . \mathrm{CO} ; 2$

Escudero A (1996) Community patterns on exposed cliffs in a Mediterranean calcareous mountain. Vegetatio 125:99-110. https://doi.org/10.1007/BF00045208

Escudero A, Palacio S, Maestre FT, Luzuriaga A (2015) Plant life on gypsum: a review of its multiple facets. Biol Rev 90:1-18. https://doi.org/10.1111/brv.12092

Fennane M, Ibn Tattou M, Mathez J, Ouyahya A, El Oualidi J (eds) (1999-2015) Flore pratique du Maroc. Manuel de détermination des plantes vasculaires, 3 vols. Travaux de l'Institut Scientifique, Série Botanique, Rabat

Fernández-Mazuecos M, Jiménez-Mejías P, Martín-Bravo S, Buide ML, Álvarez I, Vargas P (2016) Narrow endemics on coastal plains: Miocene divergence of the critically endangered genus Avellara (Compositae). Plant Biol (Stuttg) 18:729-738. https://doi.org/10.1111/plb.12458

Flora-On (2014) Flora de Portugal Interactiva. https://www.flora-on.pt. Accessed 30 May 2019

Fuertes-Aguilar J, Nieto-Feliner G (2003) Additive polymorphisms and reticulation in an ITS phylogeny of thrifts (Armeria, Plumbaginaceae). Mol Phylogenet Evol 28:430-447. https://doi.org/10.1016/S1055 $-7903(02) 00301-9$

Gaston KJ (1994) Rarity. Chapman \& Hall, London

Gaston KJ (1991) How large is a species' geographic range? Oikos 61:434-438. https://doi. org/10.2307/3545251

Gaston KJ, Blackburn TM (2000) Pattern and process in macroecology. Blackwell Science, Oxford

Gaston KJ, Fuller RA (2008) Commonness, population depletion and conservation biology. Trends Ecol Evol 23(1):14-19. https://doi.org/10.1016/j.tree.2007.11.001

Gaston KJ, Fuller RA (2009) The sizes of species' geographic ranges. J Appl Ecol 46:1-9. https://doi.org/10 $.1111 / \mathrm{j} .1365-2664.2008 .01596 . \mathrm{x}$

Gaston KJ, He F (2010) Species occurrence and occupancy. In: Magurran AE, McGill BJ (eds) Biological diversity. Oxford University Press, Oxford, pp 141-151

Georghiou K, Delipetrou P (2010) Patterns and traits of the endemic plants of Greece. Bot J Linn Soc 162:130-422. https://doi.org/10.1111/j.1095-8339.2010.01025.x

Giménez E, Melendo M, Valle F, Gómez-Mercado F, Cano E (2004) Endemic flora biodiversity in the south of the Iberian Peninsula: altitudinal distribution, life forms and dispersal modes. Biodivers Conserv $13: 2641-2660$

GLORIA (2019) Global Observation Research Initiative in Alpine environments. Glob. Obs. Res. Initiat. Alp. Environ. https://gloria.ac.at/. Accessed 30 May 2019 
Gómez-Ortiz A, Sanjosé-Blasco JJ, Salvador-Franch F, Palacios D, Salvà-Catarineu M, Oliva M, Tanarro LM, Atkinson A (2014) El proceso de degradación de hielos glaciares relictos y permafrost en Sierra Nevada (Península Ibérica): el caso del glaciar rocoso del Corral del Veleta. Avances. Métodos y Técnicas En El Estudio Del Periglaciarismo. Publicacions i Edicions de la Universitat, Barcelona, pp $149-160$

Harrison S, Noss R (2017) Endemism hotspots are linked to stable climatic refugia. Ann Bot 119:207-214. https://doi.org/10.1093/aob/mcw248

Hodgson JG (1991) Management for the conservation of plants with particular reference to the British flora. In: Spellerberg IF, Goldsmith FB, Morris MG (eds) The scientific management of temperate communities for conservation; The 31st Symposium of the British Ecological Society, Southampton 1989. Blackwell Scientific Publications, Oxford, pp 81-102

Hughes CE, Atchinson GW (2015) The ubiquity of alpine plant radiations: from the Andes to the Hengduan Mountains. New Phytol 207:275-282. https://doi.org/10.1111/nph.13230

IUCN (2012) IUCN red list categories and criteria, 2nd edn. IUCN, Cambridge

Kassambara A, Mundt F (2017) Factoextra: Extract and Visualize the Results of Multivariate Data Analyses. R package version 1.0.5. https://cran.r-project.org/web/packages/factoextra/index.html

Knapp S (2011) Rarity, species richness, and the threat of extinction-are plants the same as animals? PLoS Biol 9:e1001067. https://doi.org/10.1371/journal.pbio.1001067

Kruckeberg AR, Rabinowitz D (1985) Biological aspects of endemism in higher plants. Annu Rev Ecol Syst 16:447-479. https://doi.org/10.1146/annurev.es.16.110185.002311

Kuhn M (2008) Building predictive models in using the caret package. J Stat Softw 28(5):1-26. https://doi. org/10.18637/jss.v028.i05

Lavergne S, Thompson JD, Garnier E, Debussche M (2004) The biology and ecology of narrow endemic and widespread plants: a comparative study of trait variation in 20 congeneric pairs. Oikos 107:505-518. https ://doi.org/10.1111/j.0030-1299.2004.13423.x

Lavergne S, Thuiller W, Molina J, Debussche M (2005) Environmental and human factors influence rare plant local occurrence, extinction and persistence: a 115-year study in the Mediterranean region. J Biogeogr 32:799-811. https://doi.org/10.1111/j.1365-2699.2005.01207.x

Le Roux JJ, Hui C, Castillo ML, Iriondo JM, Keet J-H, Khapugin AA, Médail F, Rejmánek M, Theron G, Yannelli FA, Hirsch H (2019) Recent anthropogenic plant extinctions differ in biodiversity hotspots and coldspots. Curr Biol 29(17):2912-2918. https://doi.org/10.1016/j.cub.2019.07.063

Lê S, Josse J, Husson F (2008) FactoMine: an R package for multivariate analysis. J Stat Softw 25(1):1-18. https://doi.org/10.18637/jss.v025.i01

Major J (1988) Endemism: a botanical perspective. In: Meyers AA, Giller PS (eds) Analytical biogeography. Chapman \& Hall, London and New York, pp 117-146

Martínez-Hernández F, Pérez-García FJ, Garrido-Becerra JA, Mendoza-Fernández AJ, Medina-Cazorla JM, Martínez-Nieto MI, Calvente MEM, Poveda JFM (2011) The distribution of Iberian gypsophilous flora as a criterion for conservation policy. Biodivers Conserv 20:1353-1364. https://doi.org/10.1007/s1053 1-011-0031-2

Médail F, Verlaque R (1997) Ecological characteristics and rarity of endemic plants from southeast France and Corsica: implications for biodiversity conservation. Biol Conserv 80:269-271. https://doi.org/10.1016/ S0006-3207(96)00055-9

Molina-Venegas R, Aparicio A, Pina FJ, Valdés B, Arroyo J (2013) Disentangling environmental correlates of vascular plant biodiversity in a Mediterranean hotspot. Ecol Evol 3:3879-3894. https://doi.org/10.1002/ ece 3.762

Moreno JC (ed) (2010) Lista Roja de la Flora Vascular Española 2008. Actualización con los datos del Adenda 2010 al Atlas y Libro Rojo de la Flora Vascular amenazada. Dirección General de Conservación de la Naturaleza y Sociedad Española de Biología de la Conservación de Plantas, Madrid

Mota JF, Garrido-Becerra JA, Merlo ME, Medina-Cazorla JM, Sánchez-Gómez P (2017) The edaphism: gypsum, dolomite and serpentine flora and vegetation. In: Loidi J (ed) The vegetation of the iberian peninsula. Plant and Vegetation, Springer, Cham, pp 277-354

Mota JF, Medina-Cazorla JM, Navarro FB, Pérez-García FJ, Pérez-Latorre A, Sánchez-Gómez P, Torres JA, Benavente A, Blanca G, Gil C, Lorite J, Merlo ME (2008) Dolomite flora of the Baetic Ranges glades (South Spain). Flora 203:359-375. https://doi.org/10.1016/j.flora.2007.06.006

Mota JF, Sánchez-Gómez P, Merlo ME, Catalán P, Laguna E, De la Cruz M, Navarro-Reyes FB, Marchal F, Bartolomé C, Martínez Labarga JM, Sainz-Ollero H, Valle F, Serra L, Martínez-Hernández F, GarridoBecerra JA, Pérez-García FJ (2009) Aproximación a la checklist de los gipsófitos ibéricos. Anales Biol. 31:71-80

Mota JF, Sánchez-Gómez P, Guirado JS (2011) Diversidad vegetal de las yeseras ibéricas. ADIF y Mediterráneo Asesores Consultores, Almería

Munson SM, Sher AA (2015) Long-term shifts in the phenology of rare and endemic Rocky Mountain plants. Am J Bot 102:1268-1276. https://doi.org/10.3732/ajb.1500156 
Ohlemüller R, Anderson BJ, Araujo MB, Butchart SHM, Kudrna O, Ridgely RS, Thomas CD (2008) The coincidence of climatic and species rarity: high risk to small-range species from climate change. Biol Lett 4:568-572. https://doi.org/10.1098/rsbl.2008.0097

Peñas J, Benito B, Lorite J, Ballesteros M, Cañadas EM, Martinez-Ortega M (2011) Habitat Fragmentation in arid zones: a case study of linaria nigricans under land use changes (SE Spain). Environ Manage 48:165176. https://doi.org/10.1007/s00267-011-9663-y

Pereira AJ, Francisco A, Porto M (2016) Flora-On: occurrence data of the vascular flora of mainland Portugal. PhytoKeys 69:105-119. https://doi.org/10.3897/phytokeys.69.9432

Pérez-Luque AJ, Sánchez-Rojas CP, Zamora R, Pérez-Pérez R, Bonet FJ (2015) Dataset of phenology of mediterranean high-mountain meadows flora (Sierra Nevada, Spain). PhytoKeys 46:89-107. https://doi. org/10.3897/phytokeys.46.9116

Plaza Arregui L, Rodríguez Hiraldo C (2009) La recuperación de Linaria lamarckii. Conservación Vegetal 13:16-17

Quézel P (1995) La flore du bassin méditerranéen: origine, mise en place, endémisme. Ecologia Mediterranea 21:19-39

Rabinowitz D (1981) Seven forms of rarity. In: Synge H (ed) The biological aspects of rare plant conservation. John Wiley \& Sons, Chichester, pp 205-217

Raunkiaer C (1934) The life forms of plants and statistical plant geography; being the collected papers of C. Raunkiaer. Clarendon Press, Oxford

Reveal JL (1981) The concept of rarity and population threats in plant communities. In: Morse LE, Henefin ME (eds) Rare plant conservation. Bronx, New York Botanical garden, pp 41-46

Rhazi L, Grillas P, Toure AM, Ham LT (2001) Impact of land use in catchment and human activities on water, sediment and vegetation of Mediterranean temporary pools. Comptes Rendus l'Academie des Sci Ser III 324:156-177. https://doi.org/10.1016/S0764-4469(00)01286-5

Róis AS, Sádio F, Paulo OS, Teixeira G, Paes AP, Espírito-Santo D, Sharbel TF, Caperta AD (2016) Phylogeography and modes of reproduction in diploid and tetraploid halophytes of Limonium species (Plumbaginaceae): evidence for a pattern of geographical parthenogenesis. Ann Bot 117:37-50. https://doi. org/10.1093/aob/mcv138

Rovira AM (2008) Planta del Mes núm 5: Seseli farrenyi. Portal Biol. la Conserv. plantes. Lab. Botànica, Fac. Farmàcia, Univ. Barcelona. https://hdl.handle.net/2445/27726. Accessed 30 May 2019

Schwartz MW, Simberloff D (2001) Taxon size predicts rates of rarity in vascular plants. Ecol Lett 4:464-469. https://doi.org/10.1046/j.1461-0248.2001.00241.x

Silcok JL, Fensham RJ (2018) Using evidence of decline and extinction risk to identify priority regions, habitats and threats for plant conservation in Australia. Aust J Bot 66:541-555. https://doi.org/10.1071/BT18056

Smyčka J, Roquet C, Renaud J, Thuiller W, Zimmerman NE, Lavergne S (2017) Disentangling drivers of plant endemism and diversification in the European Alps-A phylogenetic and spatially explicit approach. Perspect Plant Ecol Evol Syst 28:19-27. https://doi.org/10.1016/j.ppees.2017.06.004

R Core Team (2018) R: A language and environment for statistical computing. R Foundation for Statistical Computing, Vienna

Rundel PW, Arroyo MTK, Cowling RM, Keeley JE, Lamont BB, Vargas P (2016) Mediterranean biomes: evolution of their vegetation, floras, and climate. Annu Rev Ecol Evol Syst 47:383-407. https://doi. org/10.1146/annurev-ecolsys-121415-032330

Soltis DE, Mort ME, Latvis M, Mavrodiev EV, O’Meara BC, Soltis PS, Burleigh JG, Rubio de Casas R (2013) Phylogenetic relationships and character evolution analysis of Saxifragales using a supermatrix approach. Am J Bot 100:916-929. https://doi.org/10.3732/ajb.1300044

Thompson JD (2005) Plant evolution in the Mediterranean. Oxford University Press, Oxford. https://doi. org/10.1093/acprof:oso/9780198515340.001.0001

Thompson JD, Lavergne S, Affre L, Gaudeul M, Debussche M (2005) Ecological differentiation of Mediterranean endemic plants. Taxon 54:967-976. https://doi.org/10.2307/25065481

Tison JM, Foucault B de (2014) Flora Gallica: flore de France / Jean-Marc Tison [rédacteur principal], Bruno de Foucault [animateur du projet]; dessins de François Guiol. LK-https://ucm.on.worldcat.org/oclc/90806 1314, TA-TT-. Biotope, Mèze SE-XX, 1195 p.: il.

Venables WN, Ripley BD (2002) Modern applied statistics with S, 4th edn. Springer, New York

Verdú M, Pausas JG (2013) Syndrome-driven diversification in a Mediterranean ecosystem. Evolution 67:17561766. https://doi.org/10.1111/evo.12049

WCS (2005) Wildlife Conservation Society and Center for International Earth Science Information NetworkCIESIN-Columbia University. Last of the Wild Project, Version 2, 2005 (LWP-2): Global Human Influence Index (HII) Dataset (Geographic). Palisades: NASA Socioeconomic Data and Applications Center (SEDAC). 
Wei T, Simko V (2017) R package "corrplot": Visualization of a Correlation Matrix (Version 0.84). https://githu b.com/taiyun/corrplot

Wickham H (2016) ggplot2: elegant graphics for data analysis. Springer-Verlag, New York

Yin D, He F (2014) A simple method for estimating species abundance from occurrence maps. Methods Ecol Evol 5:336-343. https://doi.org/10.1111/2041-210X.12159

Zacharias I, Zamparas M (2010) Mediterranean temporary ponds. A dissappearing ecosystem Biodivers Conserv 19:3827-3834. https://doi.org/10.1007/s10531-010-9933-7

Publisher's Note Springer Nature remains neutral with regard to jurisdictional claims in published maps and institutional affiliations. 